Bhatter College Journal of Multidisciplinary Studies

Approved by the UGC (Serial No. 629, Subjects: Education, Broad category: Social Sciences)

ISSN 2249-3301, Vol. VII, Number 1, 2017

Article url: www.bcjms.bhattercollege.ac.in/v7/n1/en-v7-01-01.pdf

Article DOI: 10.25274/bcjms.v7n1.en-v7-01-01

\title{
Banaras as Text: Representation of Widows in Mona Verma's The White Shadow
}

\author{
Ankur Konar \\ Assistant Professor, Department of English, Sir Rashbehari Ghosh Mahavidyalaya.Email: ankrknn@gmail.com
}

\begin{abstract}
:
The interplay of suppression, oppression, repression, compression of identity is an apt summary of the widows living in India. Such long practiced derelict, desolate state of the widows marks them to be somewhat 'unwanted' in our so called progressive society. This article will take up Mona Verma's novel The White Shadow, a novel set in the city of widows, that is Banaras, to discuss how the five-year-old Brinda is widowed after being married for a few hours. The child widow becomes an unwanted figure as her family refuses to take her back and she is placed in the Nirmala Ashram, the marginal place within the centre of the city. Allied with a sense of metaphor, this marginalisation relegates Brinda in particular and the widows in general to be parasitic in nature, lacking any individual identity. Taking cue from some social studies on widowhood this article will focus on how Banaras becomes vibrant with the voices of these silent widows!
\end{abstract}

Keywords: Banaras, City, Urban, Widow

Banaras is not just the past revisited. Its enigma hits you instantly and takes you back to the atavistic fulcrum ... an air dense with a rich repository of legends, myths and life so complacently settled with death is the true essence of this city. Banaras' antiquity leaves an indelible relic on the mind, with its sepia toned 'present' of an ageless past. (Verma 52)

The interplay of suppression, oppression, repression of identity is an apt summary of the widows living in India. Such long practiced derelict, desolate state of the widows marks them to be somewhat 'unwanted' in our so called progressive society. This article will take up Mona Verma's novel The White Shadow (2014), a novel set in the so-called city of widows that is Banaras to discuss how the five-year-old Brinda is widowed after being married for a few hours. The child widow becomes an unwanted figure as her family refuses to take her back and she is placed in Nirmala Ashram, the marginal place within the very centre of the city. ${ }^{1}$ Allied with a sense of metaphor, this marginalisation relegates Brinda in particular and the widows in general to be parasitic in nature, lacking any individual identity. Vis-à-vis the slender position of widows in the society, Banaras becomes vibrant with the voices of these silent widows!

It is an undeniable truth that the concept of widowhood bears a notion of negativity in Indian society. Women writers have formed a site of resistance by documenting their own experiences as women. Swarnakumari Debi's Snehalata ba Palita, Shanta Debi's Jeebandola, Ashapurna Debi's Dui Meru and Bani Basu's Shwet Patharer Thala, Usha Devi Mitra's Pia and Indira Goswami's Datal Hatir

Editor-in-Chief: Dr. Pabitra Kumar Mishra. Published by Bhatter College, Dantan. NAAC accredited A grade college.

P.O. Dantan, Paschim Medinipur, West Bengal, India. www.bhattercollege.ac.in. (C Bhatter College, Dantan 
Une Khowa Howdah have all focused on the helpless and hapless position of widows in India. Mona Verna's The White Shadow is the latest addition to this list where the problems of widows are scripted by women. The novel opens with a natural calamity that terribly hits the village Ghurni:

The villagers of Ghurni would be amassed into a heap and the funeral pyre will be lit. The back plumes of smoke would rise in soft swirls over the river and Ghurni would be forgotten. God had been unbending on his decision to destroy. There was no time to ruminate on the macabre that they were to leave behind - the untimely death of unused lives. (Verma 41)

Symbolically, the natural calamity strikes Brinda and her marital status becomes invalidated. The storm that causes death to many a villager including Brinda's husband Bisbass causes death to Brinda's childhood as well. In fact the spontaneity of childhood that remained even in the postmarital days is suddenly forced into the maturity of widowhood. With an obviousness, the birth of widowhood comes at the cost of the death of childhood as the novelist observes: "The life she was to live now was to be just the crocheted trimmings of the idyllic childhood she was living just a few days ago" (66). It is the new world of restrictions where spontaneity is largely cabined, cribbed and confined. As far as long practiced social customs are concerned, widows have no right to enter temples or to even attend marriage ceremonies; even Kanta in the novel under discussion warns: "Showing those teeth does not suit a widow" (Verma 79). Due to this hypocrisy of religion the widows are twice removed from opportunity; a latent sense of double marginalization is prevalent here: "A widow suffers from double deprivations for her dual status as woman and widow" (Bhattacharjee 7, emphasis added). Virtually, the idea of widowhood contains a journey into the world of discipline and punishment, into the world of surveillance.

As far as the growth of the plot of The White Shadow is concerned, surprisingly enough, Brinda's own father refuses to take her daughter back as the pradhan of that village warns: "She is a bad omen, ashubho lokkhon ... she brought misery upon a burgeoning flourishing village" (Verma 44). The pradhan's statement clearly establishes the fact that in this society female children are not valued as male children; rather they are often considered as economic and social burdens. ${ }^{2}$ The novelist comments that the social status of the child widows "decimated to a mere blotch of bad omen, they were relegated to spend their after years in Banaras or Vrindavan - begging and singing hymns outside temples" (48). Brinda's father-in-law Bibhuti sends her to Nirmala Ashram in Banaras. In spite of his initial determination, Bibhuti cannot keep her in his own association due to his contagious disease. On the other hand, he, like a responsible father figure, protects Brinda and 'benignly' uproots her from a storm affected village to a colourful city. Metaphorically this journey contains a journey of Brinda from childhood to widowhood. ${ }^{3}$ Her new world Banaras is generally considered to be a city of transition and transformation as we find in Verma's narration on the city space:

The only city in the world with two cremation Ghats right in the heart of the city, the Harishchandra Ghat and the Manikarnika Ghat, Banaras still manages to retain its mystical beauty. Where death is feared in other parts of the world, it is currency in Banaras. The dead are evaporated in dark swirls of smoke and life's stories are forever sedimented in the river's womb. Entering into another world is everyday business here. (52-3)

As far as the spatial dialectics are concerned, the ghats of Banaras may well be compared to the streets of Dublin or Kolkata. It will be interesting to know how the future course of Brinda's life would be changed in this proverbial city of transition. At this point it would be relevant to mention how the novelist warns the reader: "Child widows were ostracised, sent to ashrams in Banaras or 
Vrindavan to beg and fend for themselves" (42). It is obvious that widowhood becomes an 'industry' in this city. If Jaipur is called the pink city of India, Banaras, allied with a symbolic dimension, may be considered as the 'white city' because of the highest level of concentration of widows in this city. The outsider to this city Uday's photography and the textual references to the vivid details of the city - rickety rickshaws, overcrowded streets, lanes and ghats, two thousand temples, paans of various flavours indicate how the city space is constantly there in the making of this novel. ${ }^{4}$ Led by Vasanti Bua, Nirmala Ashram, a shelter house for twenty eight widows becomes Brinda's new home - in fact, her new world. Bibhuti's peeping into this world of widows reveals the pathetic, inhuman wretchedness of the dwellers:

Bibhuti ... was shocked to see a decrepit hovel where the widows, some no more than children themselves, sat hunched on their knees in a circle rolling cotton into long cylindrical wicks for the temples that ironically, they weren't permitted to even enter ... It would fetch them a measly sum for their frugal meal of boiled rice with just a pinch of salt thrown in for taste ... each of them alone on the inside, bound by a common thread of betrayal on the outside. (Verma 55-6)

This outside-inside duality always plays a part in the representation of the widows. Irony is very much part of the widows' lives in this part of the world: "Banaras was rife with widows being summoned for illicit relations and Vasanti had stoically resisted the intrusion of this infamy into her ashram" (Verma 61). Abject poverty and begging become an unavoidable truth of their life. In spite of the textual reference to the Human Rights Commission's attempt to eradicate this abject suffering of the child widows, the present text does not offer any picture of hope for the child widows.

The literary critic Rajul Sogani in the oft-cited book The Hindu Widow in Indian Literature (2002) has tried to pick up the theme of widowhood in the writings of various parts of India; from this book the readers have come to know that the very first Indian novel on the theme of widowhood was Baba Padmanji Mulay's Marathi novel Yamuna Paryatan (1857), a novel that focuses on remarriage of widows as a practical solution to the innumerable problems they face. In this book, through the analysis of the pre-Independence and post-Independence Indian novels, the author points out the changing attitudes of progressive society towards widows. In Verma's depiction of the city the widows are ironically living through plural deaths every day. At the critical juncture of Vasanti Bua's death that occurs in the last part of the text, it would not be an exaggeration to say that sati dab (widow immolation) has taken a new sophisticated turn. Uday's lens has been used to capture the plight of the widows in this city; in fact the following statements are the apt summary of the widows living in Banaras: 'These women in squalid living conditions, on one meal a day, they don't even have enough for their own cremation socially ostracised, they have separate ghats on the Ganga; and worse still, no individual history, just a collective end" (Verma 168). Vis-à-vis the spatial dialectics of Nirmala Ashram and the group formation of the widows, it would be relevant to mention that the social critic T. Blockland in Urban Bonds (2003) notes how social groups are constructed in the city space for the common interest of the group members. Furthermore, in her seminal work The Cultures of Cities (1995), Sharon Zukin rightly hints the construction of unequal power relations in cities: "The look and feel of cities reflect decision about what - and who - should be visible and what should not" (7).

Vasanti becomes an institution to safeguard the status quo of the widows in mainstream society. But she gets no helping hand from this so called progressive urban society. ${ }^{5}$ Vis-à-vis the rapacious landlord's hunger for young flesh and various adversities and oddities in this city Banaras does not offer nirvana. Thus Vasanti's continuous reading out from Bhagavad Gita is a deliberate strategy of the novelist to indicate the ironical grip of the society - the impossibility of achieving nirvana in this so- 
called holy city and the ongoing marginalization within the very centre of the city. The social critic Adinarayana Reddy in the book Problems of Widows in India (2004) has pointed out that the death of the husband has been made to signify the social death of a woman. In stark contrast to this observation, Verma's text does not offer the message that the widows have to face problems because of the absence of their husbands; rather the text offers a note of dissatisfaction vis-à-vis the role of male characters in the women's lives: "For once Kanta had a point. Men had a history of discarding their object of passion once they were done with them. Women on the other hand, more often than not, never considered lust as the motive to get involved. A touch clings to them for life" (Verma 233). Taking cue from Sandra Harding's observation that "women's lives" constitute an "objective location" (123), Verma's novel offers a discursive probe into the issue of widowhood as not only the site of sexual death but also social death.

Verma, like other writers on this city, goes into the roots of the city. ${ }^{6}$ The ironical nature of the title invites us to read the unsubstantial shadows in which whiteness, the metaphorical colour of widowhood, is thrust upon a virtually meaningless existence of the child widows: "Brinda, a white shadow, always there but never realised - just like our karma, it may elude its presence, but never lets its significance fail. The consequences never miscarry" (Verma 260). Vis-à-vis the representation of the 'invisible' widows and invisible problems in the landscape of Banaras, it is important to note that the city forms a major strand in the novelist's awareness. ${ }^{7}$ The interplay of the modernization of the urban space and the marginalization of the widow within a status quoist order of social relations clearly demands a reader-centric approach that Banaras is not a smart city.

\section{Notes:}

1. The famous film-maker Deepa Mehta's critically acclaimed film Water (2006) is also about child widows and also set in an ashram of Banaras during late 1930s.

2. "With marriage and child bearing being identified as central female functions, the redundancy of higher education for women was thus sought to be sociologically and scientifically validated" (Sen 4).

3. Mention may be made of the three year old girl's journey into faith in Verma's other novel God is a River (2011).

4. Vis-à-vis the urban frontier of Banaras, the city space is famous for paan and this obsession of the city with the flavour of paan is well captured in the Amitabh Bachchan-starrer Don (1978), directed by Chandran Barot. Even in recent times the Bengali film director Arindam Sil focuses his lens on this city space in his movie Har Har Byomkesh (2014).

5. The urban critic D.B Krishna Kumari in the essay "Urbanization Policy - An Evaluation from a Gender Perspective" writes: "Pauperization, marginalization and casualization are considered as features of women in the urban areas. Therefore, recognition of women's needs like practical gender needs and strategic gender needs must be given priority in the policy of urbanization" (Venkateswarlu 28).

6. The fictional spaces in Munshi Premchand's Bazaar-e-Husn (1919), Bibhutibhushan Bandyopadhyay's Pather Panchali (1929), Pankaj Mishra's The Romantics (1999), M.T.V. Nair's Varanasi (2002), Chetan Bhagat's Revolution 2020: Love, Corruption, Ambition (2011), Geoff Dyer's Jeff in Venice, Death in Varanasi (2011) have celebrated and textualised the city spaces of Banaras.

7. When Bibhuti enters into Banaras with Brinda, Verma writes: "To be able to recognise, accept and surrender to the truth of life is what pulls them to this most ancient city" (53). 
5 | Banaras as Text: Representation of Widows in Mona Verma's The White Shadow

\section{Works Cited}

Bhattacharjee, Jhimli. "Depiction of Widowhood in Bengali Films with a special emphasis on Sati, Chokher Bali, and Swet Patharer Thala." Research Journal of Language, Literature and Humanities Vol. 1(8), December (2014). 6-9. Web. Accessed on 28, December 2015.

Blockland, T. Urban Bonds. Cambridge: Polity, 2003. Print.

Harding, Sandra. Whose Science? Whose Knowledge? Thinking from Women's Lives. Ithaca: Cornell UP, 1991. Print.

Reddy, Adinarayana. Problems of Widows in India. New Delhi: Sarup and Sons, 2004. Print.

Sen, Indrani. Women and Empire. New Delhi: Orient Longman, 2002. Print.

Sogani, Rajul. The Hindu Widow in Indian Literature. New Delhi: Oxford UP, 2002. Print.

Venkateswarlu, D., et al, eds. Facets of Urban Society in India: Processes, Problems and Development. New Delhi: Serials, 2006. Print.

Verma, Mona. The White Shadow. New Delhi: The Book Co., 2014. Print.

Zukin, Sharon. The Cultures of Cities. Cambridge: Blackwell, 1995. Print.

Dr Ankur Konar is Assistant Professor, Department of English, Sir Rashbehari Ghosh Mahavidyalaya. 